\title{
Vrede en oordeel in het evangelie volgens Lucas
}

\begin{tabular}{|c|c|}
\hline $\begin{array}{l}\text { Author: } \\
\text { Huub Welzen }\end{array}$ & \\
\hline $\begin{array}{l}\text { Affiliations: } \\
{ }^{1} \text { Titus Brandsr } \\
\text { voor de Studi } \\
\text { Spiritualiteit, } \\
\text { Universiteit, } \\
\text { Netherlands }\end{array}$ & $\begin{array}{l}\text { na Instituut } \\
\text { van } \\
\text { Radboud } \\
\text { lijmegen, The }\end{array}$ \\
\hline $\begin{array}{l}{ }^{2} \text { Department } \\
\text { Testament, Fa } \\
\text { Theology, Uni } \\
\text { Free State, So }\end{array}$ & $\begin{array}{l}\text { f New } \\
\text { culty of } \\
\text { versity of the } \\
\text { uth Africa }\end{array}$ \\
\hline $\begin{array}{l}\text { Note: } \\
\text { Dr Huub Welz } \\
\text { research asso } \\
\text { Prof. Pieter de } \\
\text { the Departme } \\
\text { Testament, Fa } \\
\text { Theology, Uni } \\
\text { Free State, So } \\
\text { Some paragra } \\
\text { heading 'De e } \\
\text { het koningsch } \\
\text { (Lc 19:11-27) } \\
\text { are based on } \\
\text { article of the } \\
\text { Theologica (se } \\
\text { 2013, 'Spiritu } \\
\text { Lucasevangeli } \\
\text { en volharding } \\
\text { Theologica } 33\end{array}$ & $\begin{array}{l}\text { en is a } \\
\text { ciate of } \\
\text { Villiers at } \\
\text { nt of New } \\
\text { culty of } \\
\text { versity of the } \\
\text { uth Africa. } \\
\text { phs, under the } \\
\text { delman die } \\
\text { ap verwerft } \\
\text { in this article } \\
\text { he published } \\
\text { uthor in Acta } \\
\text { e Welzen, H., } \\
\text { liteit van het } \\
\text { e: Verwachting } \\
\text {, Acta } \\
\text { (1), 292-314). }\end{array}$ \\
\hline $\begin{array}{l}\text { Corresponder } \\
\text { Huub Welzen }\end{array}$ & Ice to: \\
\hline $\begin{array}{l}\text { Email: } \\
\text { huub.welzen } \\
\text { titusbrandsma }\end{array}$ & Instituut.nl \\
\hline $\begin{array}{l}\text { Postal addres } \\
\text { Titus Brandsm } \\
\text { Erasmusplein } \\
\text { Nijmegen, Th }\end{array}$ & $\begin{array}{l}\text { s: } \\
\text { la Instituut, } \\
\text { 1, } 6525 \mathrm{HT} \\
\text { Netherlands }\end{array}$ \\
\hline $\begin{array}{l}\text { Dates: } \\
\text { Received: } 20 \\
\text { Accepted: } 23 \\
\text { Published: } 31\end{array}$ & $\begin{array}{l}\text { eb. } 2015 \\
\text { May } 2015 \\
\text { Aug. } 2015\end{array}$ \\
\hline Read online: & \\
\hline 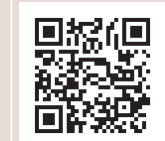 & $\begin{array}{l}\text { Scan this QR } \\
\text { code with your } \\
\text { smart phone or } \\
\text { mobile device } \\
\text { to read online. }\end{array}$ \\
\hline
\end{tabular}

Peace and judgement in the gospel according to Luke. Quite rightly Luke is called an evangelist of peace and non-violence. It is recognised in several studies that peace, nonviolence and love for the enemy are integral parts of the message of the Lucan Jesus. Yet this statement cannot be made without criticism. In the gospel of Luke there are many texts in which violence is present, which is incongruent with the message of peace and non-violence. Sometimes there is even violence that is excessive. In many of these texts violence has to do with vengeance in the judgement. In some recent studies the relation of the peace-message of Jesus and the retribution in the judgement is discussed. In this article we first examine the problem of violence in Luke's gospel with the help of Luke 19:9-27. In the vision of Luke the destruction of Jerusalem in $70 \mathrm{CE}$ is a consequence of the refusal to accept the message of Jesus. To understand this it is necessary to place the fall of Jerusalem in the eschatological timetable of Luke. We see here a certain equivalence between the situation of the contemporaries of Jesus within the gospel and the situation of the intended readers in the last quarter of the first century CE. Moreover we propose to reverse the way the question is put. We do not have to enlighten how it is possible that after the peace-message of Jesus there will be vengeance in the judgement. First there is the announcement of the judgement. After that a delay is announced for the contemporaries of Jesus as well as for the intended readers of Luke's gospel: a year of the Lord's favour. This delay gives room for repentance.

\section{De geweldloze Jezus}

Door vele exegeten is de auteur van het evangelie volgens Lucas een evangelist van de geweldloosheid genoemd. Een voorbeeld is de redaktionsgeschichtliche studie van Josephine Massyngbaerde Ford, My enemy is my guest (Massyngbaerde Ford 1984). In dit boek schildert Massyngbaerde Ford de lucaanse Jezus als een personage van absolute geweldloosheid. De teksten die ze als achtergrond gebruikt om de eigen lucaanse opvatting te profileren, zijn uiteraard de evangelies volgens Matteüs en Marcus, maar ook de boeken van de Makkabeeën, teksten uit Qumran en teksten uit de Talmoed en Misjna. Steeds laat ze zien hoe Lucas teksten die thuishoren in een revolutionair en gewelddadig milieu, teksten die getuigen van zelotische vrijheidsopvattingen, teksten die teruggaan tot de tijd van de Makkabeeën en teksten die in de eerste eeuw vooral tegen de Romeinen waren gericht, omvormt tot teksten die op een apolitieke manier geweldloosheid prediken.

Het Lucasevangelie moet men situeren na de Eerste Joodse Oorlog (66 tot 70 n. Chr.). Flavius Josephus bericht dat deze oorlog ook in de diaspora een grote doorwerking heeft gehad. Sommige revolutionairen waren naar de diaspora gevlucht en veroorzaakten daar verdere onrust. Een van de doelstellingen van het evangelie volgens Lucas is een antwoord te geven op de omstandigheden na de joodse oorlog. Volgens Massyngbaerde Ford wil dit evangelie laten zien aan Christenen in Palestina en de diaspora dat de christelijke vrede niet komt via wapengeweld, maar door liefde, vergeving en het accepteren van de vijand in de christelijke gemeenschap.

Massyngbaerde Ford meent dat de gebeurtenissen die verhaald worden in de eerste twee hoofdstukken van het Lucasevangelie nog behoren tot de periode van Israël. In deze hoofdstukken worden de families van Johannes de Doper en van Jezus geschilderd als rechtvaardige Joden die een profeet en een koning verwachten die een heilige oorlog zullen beginnen, die internationale macht voor Israël zullen verwerven en die vergelding zullen bewerken ten opzichte van Israëls vijanden. In het verhaal van de verkondiging van Jezus in de synagoge van Nazareth (Lc 4:16-30) wordt dit beeld volledig veranderd. Jezus is daar de Gezalfde die een jaar van heil vanwege God aankondigt voor Joden én voor hun vijanden. Deze boodschap wordt met zo'n

How to cite this article: Welzen, H., 2015, 'Vrede en oordeel in het evangelie volgens Lucas', HTS Teologiese Studies/Theological Studies 71(1), Art. \#2916, 11 pages. http://dx.doi.org/10.4102/hts.v71i1.2916

Copyright: @ 2015. The Authors. Licensee: AOSIS OpenJournals. This work is licensed under the Creative Commons Attribution License. 
verbazing aangehoord dat Jezus' stadsgenoten hem dreigen te vermoorden. Het aangekondigde jaar van genade zou vele van de sociale, economische en religieuze problemen in Palestina oplossen. Maar dit programma is ook toepasbaar op de christenen in de diaspora.

Massyngbaerde Ford meent dat de spanningen onder de procurator Cumanus mede aanleiding zijn geweest voor de joodse oorlog. ${ }^{1}$ Maar het optreden van Jezus raakt ook aan de andere sociale en politieke kwesties, zoals het ressentiment jegens tollenaars en zondaars en aan het probleem van de vijandschap tussen Joden en Samaritanen. Massyngbaerde Ford noemt bovendien de lex talionis en de problemen van armoede en rijkdom.

In het passieverhaal komt Lucas' visie op de vijandsliefde tot een hoogtepunt. Jezus wordt van alle beschuldigingen een politiek agitator te zijn gevrijwaard. Hij geneest het oor van de knecht van de hogepriester. Hij is de ideale martelaar die, anders dan de joodse martelaren, bidt voor zijn beulen. Hij belooft het eeuwig geluk aan een veroordeelde crimineel.

De opvattingen van Massyngbaerde Ford moeten kritisch worden beschouwd. Drie punten verdienen aandacht. Het eerstebetreft deplaats en defunctievan deeerstehoofdstukken van het Lucasevangelie. In meerdere historisch-kritische analyses is de opvatting verdedigd dat deze hoofdstukken van een andere aard zijn dan de rest van het evangelie en dat deze hoofdstukken als het ware apart gelezen moeten worden. Vanuit een synchroon en narratologisch standpunt is dat echter moeilijk vol te houden. Een dergelijke scheiding schaadt immers de narratologische integriteit van het geheel. Een lezing van het Lucasevangelie als een narratologisch geheel is in mijn ogen zeer wel mogelijk.

Een tweede punt is het scherpe onderscheid dat Massyngbaerde Ford maakt tussen politiek en religieus, vooral in haar analyses van het lijdensverhaal. Men kan het mijns inziens niet volhouden om 'Messias' uitsluitend in politieke zin te verstaan, en 'zoon van God' uitsluitend als een religieuze term te zien. Zelf heb ik ooit voorgesteld om beide termen te verstaan tegen de achtergrond van een messiaanse jahwistische koningsspiritualiteit die vooral in het Zuidrijk is ontwikkeld (Welzen 2008, vooral 174-179). In deze spiritualiteit spelen titels als Gezalfde, zoon van God en zoon van David een belangrijke rol. In deze ideologie zijn de politieke en de religieuze domeinen met elkaar verweven.

1. Het ernstigste incident vond plaats tegen het einde van de regering van Cumanus. Flavius Josephus vertelt erover in De Joodse Oorlog 2.232-247 en Joodse Oudheden 20.118-136. Er zijn significante verschillen tussen de twee versies. Enkele joodse pelgrims uit Galilea die door Samaria naar Jeruzalem reisden, waren doo Samaritanen uit het dorp Gema overvallen en gedood. De Galileese leiders riepen Cumanus op snel in te grijpen en de daders terecht te stellen. Cumanus reageerde echter niet. Een woedende joodse menigte richtte vervolgens een bloedbad aan onder de Samaritanen. Daarop stuurde Cumanus troepen naar Sebaste om de Samaritanen te hulp te komen. Met de hulp van de Romeinen richtten de Samaritanen nu een bloedbad aan onder de Joden. Beide partijen stuurden daarop een gezantschap naar Gaius Ummidius Quadratus, de gouverneur van Syrië, om een gezantschap naar Gaius Ummidius Quadratus, de gouverneur van Syrie, om hem de zaak voor te leggen. Quadratus liet de aanvoerders van zowel de Joodse als de Samaritaanse troepen kruisigen. Cumanus onthief hij uit zijn functie en stuurde hem naar Rome om zich voor de keizer te verantwoorden, samen met delegaties van Joden en Samaritanen. De Samaritanen kozen de kant van Cumanus. De Jode werden gesteund door Herodes Agrippa Il die toevallig in Rome was. De keizer koos de kant van de Joden. De leiders van de Samaritaanse delegatie werden ter dood veroordeeld en Cumanus werd verbannen.
In deze opvatting van het koningschap speelt de belofte van Natan in 2 Samuel 7:12-16 een belangrijke rol. De uitspraken van Gabriël over de betekenis van Jezus in Lucas 1:32-33 zijn de eerste uitspraken in het Lucasevangelie over Jezus' identiteit. Deze uitspraken bevatten echo's van de belofte van Natan. De waarneming dat vele christologische benamingen van Jezus binnen deze koningsspiritualiteit te plaatsen zijn, heeft mij tot de conclusie gevoerd dat het Lucasevangelie is 'ingeschreven' in de belofte van Natan.

Een derde punt van kritiek is dat Massyngbaerde Ford systematisch de teksten die de eschatologie betreffen niet bespreekt. Daardoor blijft een bepaald spanningsveld buiten het vizier. In de teksten over het oordeel, maar ook in de teksten die het toekomstig lot van Jeruzalem betreffen, is er nogal wat geweld aanwezig. In de wijze waarop Massyngbaerde Ford het Lucasevangelie bestudeert kan de vraag niet aan de orde komen hoe de geweldloze Jezus van het Lucasevangelie zich verhoudt ten opzichte van het geweld dat bij het oordeel hoort en bij het geweld dat ook Jezus voorziet bij het toekomstig lot van Jeruzalem. De vraag naar deze verhouding komt in onze studie aan de orde.

\section{Een boodschap van vrede en een vergeldend oordeel}

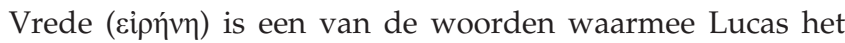
programma van Jezus benoemt. Hij gebruikt ook andere termen, zoals de woorden die behoren tot de woordgroep redden en bevrijden ( $\sigma \omega \dot{\zeta} \zeta \omega, \sigma \omega \tau \eta \dot{\rho}, \sigma \omega \tau \eta \rho i ́ \alpha, \sigma \omega \tau \eta \dot{\rho} \rho$ ióv),

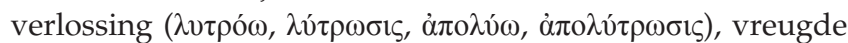
( $\chi \alpha \rho \alpha ́)$, genade ( $\chi \alpha \rho i \zeta o \mu \alpha \iota, \chi \alpha ́ \rho ı)$ en wegzenden, kwijtschelden

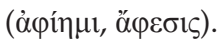

Omdat hij het thema van de vrede mist in studies naar de theologie en de ethiek van het Nieuwe Testament, heeft Willard M. Swartley een studie gemaakt naar het voorkomen van vrede in het gehele Nieuwe Testament (Swartley 2006). Hij besteedt ook aandacht aan het thema van de vrede zoals dat in Lucas en Handelingen voorkomt (Swartley 2006:121-151, 152-176). Swartley komt tot geheel andere conclusies dan Massyngbaerde Ford. Hij begint met een verkenning van de plaatsen waar het woord 'vrede' voorkomt en van de teksten die raken aan het gebod om je vijand lief te hebben. De proclamatie van het koninkrijk van God impliceert de afkondiging van vrede. Het woord 'vrede' verschijnt op strategische plaatsen in het Lucasevangelie: in de beginverhalen, en aan het begin en het einde van het reisverhaal. Wanneer mensen de vrede van het koninkrijk van God niet aannemen, volgt het oordeel. Het aanbod van vrede veroorzaakt zo een crisis die beslissend is voor de deelname aan het koninkrijk van God. Op basis van de studies van Richard J. Cassidy (Cassidy 1978) en van John Howard Yoder (Yoder [1972] 1994) laat Swartley zien dat de eerdere opvattingen omtrent het politieke karakter van het Lucasevangelie niet terecht zijn. De waarden die Jezus voorstaat contrasteren met die van het Romeinse rijk. Vooral Yoder benadrukt het revolutionaire karakter van Jezus' optreden in sociaal, politiek en economisch 
opzicht. Zijn optreden wordt gefundeerd in een theologie van het jobeljaar. Swartley draagt daarbij argumenten aan die deze theologie van het jobeljaar versterken. Door het thema van de gerechtigheid in verband te brengen met dat van de vrede laat hij zien dat het Lucasevangelie zeker geen apologie biedt van de Pax Romana. Jezus kiest als een oudtestamentische profeet de zijde van de mensen die in de marge van de samenleving moeten leven en die het slachtoffer zijn van de manier waarop de Pax Romana wordt gevestigd. Anders dan de Pax Romana is de lucaanse gemeenschap gebouwd op vrede en gerechtigheid. Wanneer mensen alleen maar gerechtigheid veinzen, heeft dat consequenties voor de gerechtigheid van God in het oordeel. In tegenstelling tot de studie van Massyngbaerde Ford komt in het werk van Swartley het spanningsveld van vrede en oordeel wel aan de orde. Swartley laat zien hoe het oordeel een gevolg is van de weigering om het aanbod van vrede te accepteren.

David J. Neville (Neville 2013:91-173) bouwt voort op het werk van Swartley. Hij stelt expliciet het spanningsveld van de vredeszending van Jezus en het vergeldingsgeweld van het oordeel in het evangelie volgens Lucas aan de orde. In het hoofdstuk 'The evangelist of peace' verkent hij vooral het thema van de vrede in de verkondiging en het optreden van Jezus (Neville 2013:91-117). Net zoals Swartley schenkt ook hij aandacht aan de strategische plaatsen in het Lucasevangelie waar het thema van de vrede verschijnt: onder andere aan het begin van het reisverhaal bij de uitzending van de tweeënzeventig (Lc 10:1-16) en bij het einde daarvan (Lc 19:29-44). Hij schenkt daarbij ook aandacht aan het lot van het Samaritaanse dorp in Lucas 9:52-56 dat Jezus niet wil ontvangen en aan het lot van Jeruzalem dat de weg naar de vrede niet heeft herkend (Lc 19:41-44). Lucas interpreteert de val van Jeruzalem in 70 na Chr. als vergelding voor de weigering om de koning van de vrede bij zijn intocht te erkennen.

In zijn analyse van het vredesthema maakt Neville een aantal belangrijke verbindingen. Zo brengt hij uitdrukkelijk het exodusthema ter sprake. De uittocht die Jezus in Jeruzalem zal gaan voltrekken is het gespreksonderwerp van Jezus, Mozes en Elia in het verhaal van de verheerlijking op de berg (Lc 9:28-36). In de ogen van Neville omvat de uittocht van Jezus niet alleen de gebeurtenissen in Jeruzalem (het lijden, de dood, de opstanding en de hemelvaart van Jezus), maar ook de reis naar Jeruzalem. Daardoor komt er een verbinding tot stand tussen de verkondiging van Jezus, de gebeurtenissen in Jeruzalem, en de eschatologische gebeurtenissen. Onderdeel van het exodusmotief is dat God zijn volk heeft bezocht (zie Lc 1:68; 1:78; 7:16; 19:44; Hnd 15:14). Het exodusmotief maakt expliciet deel uit van het programma van bevrijding, waartoe God initiatief heeft genomen. De weg van de vrede is niet alleen de weg die Jezus gaat, het is ook de weg van God die zijn volk heeft bezocht.

Aan het einde van dit hoofdstuk noemt Neville een aantal elementen die nauwelijks te harmoniëren zijn met de vredesboodschap van de lucaanse Jezus. Dat zijn vooral de gewelddadige elementen in het eschatologisch oordeel. Meer in het bijzonder is het de opvatting van Lucas dat de ondergang van Jeruzalem moet worden gezien als Gods vergelding voor het feit dat Jeruzalem Jezus en zijn vredesboodschap niet heeft aanvaard.

Hoe de relaties liggen tussen de verkondiging van Jezus, het lot van Jeruzalem en het eschatologisch oordeel verkent Neville in een volgend hoofdstuk (Neville 2013:119-144). Hij onderzoekt daarin de drie belangrijkste teksten in het Lucasevangelie die spreken over het eschaton: Lucas 12:35-48; Lucas 17:20-37; Lucas 21:5-36. Zijn conclusie is dat in Jezus' toespraak over het einde (Lc 21:5-36) het idee van eschatologische vergelding feitelijk afwezig is, terwijl in de twee andere tekstgehelen dit idee wordt gerelativeerd. Immers Lucas 12:35-48 en Lucas 17:20-37 maken deel uit van het reisverhaal dat omraamd en bepaald wordt door de vredesverkondiging van Jezus. De zending van Jezus is er de uitdrukking van dat God zijn volk heeft bezocht. Wanneer Jezus spreekt over eschatologisch geweld worden deze woorden in Lucas 12:35-40 en in Lucas 21:25-36 afgesloten met woorden waarin vergelding niet meer aan de orde is. Daardoor wordt het eschatologisch oordeel gerelativeerd. Maar de opvatting van Lucas dat Jeruzalem verwoest is als een vergelding van de afwijzing van Jezus blijft als een zware steen op de maag liggen. Het ondermijnt de vredesboodschap van Lucas en het versterkt het idee dat de komst van de Mensenzoon en de definitieve vestiging van het koninkrijk van God gepaard gaan met een vergeldend oordeel.

In het vervolg van dit artikel wil ik de ernst van de problematiek laten zien door de analyse te presenteren die Sjef van Tilborg gemaakt heeft van de parabel van de edelman die naar het buitenland gaat om het koningschap te verwerven (Lc 19:11-27). Daarna zal ik het eschatologisch tijdpad schilderen zoals dat aanwezig is in Jezus' toespraak over het einde. Dit verschilt op enkele punten van het tijdpad zoals Neville dat ziet. Dit tijdpad is van belang voor de situering van de beoogde lezers en de door Lucas veronderstelde analogie van deze situatie met de tijdgenoten van Jezus in het evangelieboek. Daarna zal ik proberen om het uitstel van de parousie te verbinden met de lucaanse theologie van het jobeljaar. Als achtergrond daarbij neem ik de aankondiging van het oordeel zoals dat aanwezig is in de verkondiging van Johannes de Doper.

\section{De edelman die het koningschap verwerft (Lc 19:11-27)}

De analyse die Sjef van Tilborg geeft van de parabel van de edelman die naar het buitenland vertrekt om daar het koningschap te verwerven (Lc 19:11-27), is buitengewoon verontrustend. ${ }^{2}$ Met name de afwisseling van stemmen aan het einde van de parabel doet nogal wat vragen opkomen bij

2.Deze analyse heb ik eerder geciteerd in verband met mijn studies naar de spirituele grondlijnen van het Lucasevangelie (Welzen 2013). 
het idee dat de Jezus van het Lucasevangelie een principiële geweldloosheid voorstaat. ${ }^{3}$

Het is een groot probleem hoe de parabel aan het einde afgebakend moet worden en hoe de spreekbeurten precies verlopen. ${ }^{4}$ Van Tilborg bespreekt drie mogelijkheden. De eerste mogelijkheid is dat de parabel doorloopt tot en met vers 27. In vers 24 is de hoofdpersoon van de parabel aan het woord. Hij zegt tot zijn omstanders om de derde slaaf het pond af te nemen en het aan de eerste te geven. Het bezwaar van de omstanders is dat deze er al tien heeft. In vers 26 en 27 vervolgt de hoofdpersoon van de parabel met een argumentatie voor zijn besluit en met het bevel om zijn vijanden die niet wilden dat hij koning werd, voor zijn ogen af te slachten. Een belangrijk tegenargument tegen deze meest eenvoudige lezing is het gebruik van de formulering $\lambda \dot{\varepsilon} \gamma \omega \dot{v} \mu \mathrm{i} v$ in Lucas 19:26. Deze formulering komt in het Lucasevangelie alleen voor in de mond van Jezus. ${ }^{5}$ Bovendien is de spreuk van Lucas 19:26 een herhaling van Lucas 8:18 waar deze spreuk door Jezus wordt uitgesproken.

Vanwege deze tegenargumenten komen sommige uitleggers tot een tweede leesmogelijkheid. In Lucas 19:24 spreekt de hoofdpersoon van de parabel tot zijn omstanders. Het bezwaar in vers 25 is afkomstig van de omstanders van de koning. In vers 26 spreekt Jezus tot zijn toehoorders die de parabel horen. In vers 27 vervolgt dan de hoofdpersoon van de parabel met het bevel om zijn politieke tegenstanders te vermoorden.

Van Tilborg wijst deze leesmogelijkheid af vanwege de erg verwarrende opeenvolging van stemmen. Hij kiest voor een derde leeswijze. Vers 24 is een bevel van de koning om de derde slaaf te straffen. In vers 25 maken de toehoorders van Jezus bezwaar tegen deze afloop van de parabel. In vers 26 en 27 gaat Jezus vervolgens in op het bezwaar dat zijn toehoorders maken. De discussie aan het einde is geen discussie tussen de koning en zijn omstanders maar tussen Jezus en zijn toehoorders. Van Tilborg wijst erop dat de parabel van de misdadige wijnbouwers (Lc 20:9-19) een soortgelijke afwisseling van stemmen heeft. In Lucas 20:16a wordt de straf genoemd die de eigenaar van de wijngaard de wijnbouwers zal toedienen. De toehoorders van Jezus wijzen deze straf af (Lc 20:16b). In de daarop volgende verzen geeft Jezus argumenten voor de afloop van de parabel die hij heeft verteld (Lc 20:17-18). Iets dergelijks is er ook aan de hand bij de parabel van de grote feestmaaltijd in Lucas

3.Mogelijk worden in het verhaal historische gebeurtenissen weerspiegeld rond de opvolging van Herodes de Grote die in 4 voor Chr. is gestorven. Zijn zoon Archelaüs was bij testament aangewezen als heer van Judea. Archelaüs vertrekt naar Rome om erkenning van zijn aanspraken te krijgen. Dat lukt, ondanks het feit dat er ook een joods gezantschap naar Rome is gegaan om kenbaar te maken dat men niet wilde dat het Herodiaanse huis nog macht zou hebben. Archelaüs wordt geen koning, maar etnarch. Na tien jaar wordt hij vanwege de voortdurende klachten van zijn onderdanen verbannen. Vanaf die tijd staat Jude onder een Romeinse procurato (Welzen 2013). Deze mogelijke verwijzingen nar historische Robeinse procurator in mijn ogen niets af aan het choquerend karakter van de parabel.

4.Zowel Swartley (2006) als Neville (2013) noemen de parabel in hun studies, maar ze gaan niet in op het probleem van de afbakening van de parabel aan het einde.

5.Deze formulering komt 41 maal voor in het Lucasevangelie. Alleen in Lucas 3:6 komt hij voor in de mond van Johannes de Doper.
14:24. In bewoordingen die ontleend zijn aan de parabel maakt Jezus zichzelf tot gastheer van de maaltijd: 'Want ik verzeker $\mathrm{u}$, geen van de mensen die genodigd waren, zal van mijn maaltijd proeven.' Het belangrijkste argument dat van Tilborg noemt is dat Jezus via de formule $\lambda \varepsilon \dot{\gamma} \omega \omega \dot{v} \mu \tilde{v}$ terugkeert naar de situatie waarin de parabel wordt verteld. ${ }^{6}$

In Lucas 12:46 is eveneens sprake van een gruwelijke straf van slaven die niet doen wat hun heer verwacht. De heer

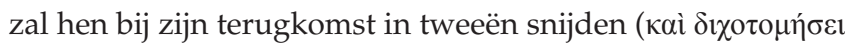
av่tòv). Van Tilborg betrekt deze tekst niet in zijn betoog. Hier is duidelijk sprake van een andere situatie dan in Lucas 19:27. De straf wordt daar voltrokken door een personage in de parabel. De straf blijft deel uitmaken van de door Jezus vertelde werkelijkheid. Dat is anders in de parabel van de edelman.

Hoewel het een schokkende lezing is, vind ik de argumenten die van Tilborg geeft overtuigend. De afwisseling van stemmen past in het patroon van Lucas. Indien men de lezing van van Tilborg aanvaardt, wordt het probleem van de verhouding van de verkondiging van Jezus, die gekenmerkt wordt door vrede en geweldloosheid, en het vergeldend geweld van het oordeel alleen maar groter. Het schokkend karakter van het verhaal wordt nog meer zichtbaar wanneer men met van Tilborg het verhaal leest in zijn lucaanse context. Vers 11 legt een onmiddellijk verband met het voorafgaande verhaal van Zacheüs en het erop volgende verhaal van de intocht. In de opvatting van van Tilborg is het verhaal in tweevoudig opzicht een correctie van de verwachtingen van de toehoorders van Jezus. Het eerste is dat de nabijheid bij Jeruzalem nog niet betekent dat het koninkrijk van God onmiddellijk komt. Er moet eerst nog een reis naar een ver land komen. De identificatie van Jezus met de edelman uit de parabel, die in 19:27 expliciet wordt gemaakt, is hier al werkzaam. De koningstitel zal aan Jezus toekomen na een vertrek naar een ver land. Er zal oppositie zijn. Intussen heeft hij aan zijn dienaren zijn bezit toevertrouwd. Wie de opdracht goed vervult, zal deelhebben aan Jezus' koningschap (vgl. Lc 22:29-30). Wie dat niet doet, is ervan uitgesloten. De toehoorders van de parabel staan voor de vraag wie ze zijn: een van de burgers of een van de slaven (zie Welzen 2013).

De tweede correctie heeft van doen met wat de toehoorders van Jezus denken. Jezus legt uit wat de komst van het koninkrijk allemaal impliceert. Hij vult als het ware de gedachten van zijn toehoorders aan. Er is niet alleen sprake van redding en verheffing (Lc 19:9-10), maar ook van ondergang en straf. Er zal rekening en verantwoording moeten worden afgelegd en het toekomstig lot is afhankelijk van hoe men door het oordeel komt (zie Welzen 2013).

Binnen de grotere context van het Lucasevangelie is de parabel een sleuteltekst. Dat is zichtbaar vanuit de reeds geconstateerde identificatie van Jezus met de edelman/ koning. Al vanaf het begin van het evangelie is Jezus

6.Zie Lucas 14:24; $15: 7,10 ; 16: 9 ; 18: 8$; $18: 14$; vergelijk ook Lucas $8: 8$ waar een andere formulering wordt gebruikt. 
gepresenteerd als een koning. Het koningschap van Jezus wordt bijzonder dramatisch wanneer het verbonden wordt met het thema van de Mensenzoon en met dat van het lot van Jeruzalem. De komst van Jezus in Jeruzalem is niet de tijd waarop het koninkrijk van God zichtbaar wordt. Wel is er een direct verband met de installatie van de Mensenzoon. Jezus wordt door zijn leerlingen gehuldigd als koning (Lc 19:28-38), maar ook door tegenstanders afgewezen (Lc 19:39-40; 20:1 e.v.). Er vindt een proces plaats, een executie en een heengaan naar de hemel. Eerder is hierover in het boek gesproken als over een uittocht (Lc 9:31) en een verheffing (Lc 9:51). Al deze gebeurtenissen horen bij de installatie van de Mensenzoon. Jezus spreekt er zelf over in Lucas 22:69: 'Vanaf nu zal de Mensenzoon zitten aan Gods machtige rechterhand.' Na de gebeurtenissen in Jeruzalem is de Mensenzoon onzichtbaar, maar hij zal opnieuw verschijnen. In de tijd dat de Mensenzoon onzichtbaar is, zal Jeruzalem verwoest worden (Lc 19:43-44; 21:20-24). Daarna zal de Mensenzoon voor iedereen zichtbaar worden en verlossing brengen (21:27-28). Dat zal gebeuren binnen de tijd van één generatie (Lc 21:32). Het is tegelijk het verschijnen van het koninkrijk van God (Lc 21:31) (zie Welzen 2013).

De woorden van de sympathisanten van Jezus bij de intocht in Lucas 19:38 zijn prematuur als er mee bedoeld is dat de intocht het vestigen van het koninkrijk van God is. Wel is het het begin van de gebeurtenissen te Jeruzalem; dat wil zeggen, van de uittocht en de verheffing van de Mensenzoon en het innemen van diens plaats aan de rechterhand van God (zie Welzen 2013).

Binnen deze grotere context is Lucas 19:27 een verwijzing naar de verwoesting van Jeruzalem, de moord op haar inwoners en kinderen (Lc 19:43-44) en het verkocht worden als krijgsgevangenen aan de heidenen (Lc 21:20-24). In het Lucasevangelie is het al eerder gezegd. Als de toehoorders van Jezus zich niet bekeren, zal hen hetzelfde overkomen als wat met de Galileeërs is gebeurd die Pilatus heeft vermoord en met de achttien die onder de toren van de Siloam zijn omgekomen (Lc 13:1-5). Jezus heeft dikwijls de kinderen van Jeruzalem bij elkaar willen brengen, zoals een kloek haar kuikens, maar ze hebben niet gewild. Hun huis zal onbewoond achtergelaten worden (Lc 13:34-35). Hetzelfde wordt gezegd in de parabel van de wijnboeren: de heer van de wijngaard zal komen en de boeren uitroeien (Lc 20:16). Jezus is de steen die de bouwlieden hebben verworpen. Ieder die op deze steen valt, valt te pletter, en ieder op wie hij valt, zal hij verbrijzelen (Lc 20:18). Maar dit is niet het einde (Lc 21:28). Het einde is wanneer de Mensenzoon komt (Lc 21:27), wanneer de verlossing nabij is (Lc 21:28), wanneer het koninkrijk van God dichtbij is (Lc 21:31) (zie Welzen 2013).

In de voorstelling van Lucas is Jezus dus iemand die de bewoners van Jeruzalem voortdurend heeft voorgehouden dat de laatste kans is aangebroken. Als ze zich bekeren zullen ze het noodlot dat Jeruzalem bedreigt, kunnen voorkomen (zie Welzen 2013).

\section{Situering van de beoogde lezers van het Lucasevangelie}

De studie van van Tilborg is uitgevoerd in het kader van een onderzoeksproject naar de pragmatische werking van de parabelverhalen in het Lucasevangelie. ${ }^{7}$ De werkhypothese van dit project was de volgende: de voorstelling die Lucas geeft van de werking van de verhalen, verteld door de hoofdfiguur van zijn boek, geeft de richting aan van de werking die hij beoogt of verwacht van zijn boek. Bij de voltooiing van het onderzoek is een meer toegespitste formulering als voorlopig geverifieerd beschouwd (Welzen 1987, vooral 317-319). In deze toespitsing worden de termen transformatie en equivalentie ingevoerd. De meer toegespitste formulering luidt:

$\begin{array}{ll}\text { De wijze waarop } & \text { A1 } \\ \text { de verteller van het inbeddend verhaal } & 2 \\ \text { de (vertelde) verteller van de ingebedde verhalen } & 3 \\ \text { door deze verhalen } & 4 \\ \text { en hun toelichting } & 5 \\ \text { bij de (vertelde) toehoorders van deze verhalen } & 6 \\ \text { een transformatie doet nastreven } & 6 \\ \text { die betrekking heeft op instemming of afwijzing van } & 8 \\ \text { een waardensysteem } & 9 \\ \text { is equivalent aan } & \text { equivalentie } \\ \text { de wijze waarop } & \text { B1 } \\ \text { de verteller van het inbeddend verhaal } & 2 \\ \text { zelf } & 3 \\ \text { door zijn verhaal } & 4 \\ \text { en zijn toelichtingen } & 4 \\ \text { bij de lezers van het inbeddend verhaal } & 8 \\ \text { een transformatie doet nastreven } & \\ \text { die betrekking heeft op instemming of afwijzing van } & 6 \\ \text { een waardensysteem. } & 8\end{array}$

De term 'equivalentie' wil recht doen aan het verschil tussen de communicatie zoals die in het boek van Lucas tussen Jezus en zijn toehoorders plaats heeft, en de communicatie tussen de auteur en zijn lezers. Deze twee communicatieve situaties hoeven niet in alle opzichten aan elkaar gelijk te zijn. Belangrijk is wel dat het betreffende waardensysteem in beide situaties herkenbaar aanwezig is. De term transformatie duidt op de veranderingen die in beide communicatieve situaties bij de ontvangers verwacht of beoogd worden. In de situatie van Jezus en zijn toehoorders speelt de communicatie zich af binnen het vertelde evangelieverhaal. Jezus probeert bij zijn toehoorders een verandering te bewerken in hun waardering van het waardensysteem dat aanwezig is in zijn verkondiging van het koninkrijk van God. Op een soortgelijke manier probeert Lucas bij zijn beoogde lezers een verandering te bewerken ten aanzien van hetzelfde waardensysteem. Deze communicatie speelt zich af in een andere situatie dan die tussen Jezus en zijn toehoorders.

Bij de parabelverhalen komt er nog een communicatieve situatie bij: die tussen de personages van het parabelverhaal. Het resultaat van het onderzoek naar de parabelverhalen

\footnotetext{
7.Dit project is uitgevoerd aan de theologische faculteit van de Radboud Universiteit (toen nog Katholieke Universiteit) te Nijmegen. De resultaten zijn in twee publica derij in twee publicaties openbaar gemaakt (Welzen 1986; van lersel et.al. 1987).
}

8 .In de gepubliceerde tekst staat 'nastreeft'. De fout is hier gecorrigeerd. 
in het Lucasevangelie bestaat nu in de stelling dat er een analogie is in de relatie tussen wat er in het parabelverhaal gebeurt en de situatie waarin Jezus dit parabelverhaal vertelt enerzijds en anderzijds de situatie in het evangelieverhaal en de situatie van de door Lucas beoogde lezers. In het geval van de parabel van de edelman die het koningschap verwerft, wordt de pragmatische werking van het ingebedde verhaal in de situatie waarin Jezus dit verhaal vertelt, geïntensifieerd doordat Jezus de terminologie van het parabel overneemt en zich identificeert met de koning van het verhaal. De politieke vijanden van de koning zijn daardoor Jezus' vijanden geworden. Jezus zelf is het die de opdracht geeft zijn vijanden af te slachten. Welke choquerende gevolgen dit heeft is in de analyse van van Tilborg duidelijk geworden. We nemen aan dat dit gruwelijke element ook zijn invloed heeft in de persuasieve werking van het evangelieverhaal naar de boogde lezers.

Om een goed beeld te krijgen van de situatie van de beoogde lezers in relatie met de problematiek van een verkondigde geweldloosheid en een aangekondigde vergelding zijn twee waarnemingen belangrijk. De eerste is dat het Lucasevangelie door vrijwel iedereen gedateerd wordt in het laatste kwart van de eerste eeuw. We zien geen reden om deze communis opinio aan te vechten. Dat betekent onder meer dat de gebeurtenissen van de joodse oorlog, de val van Jeruzalem en de verwoesting van de tempel voor de beoogde lezers verleden tijd zijn. Voor de personages in het boek van Lucas zijn ze dit echter niet. Voor Jezus en zijn toehoorders is het allemaal nog toekomst. Wat Jezus in het boek zegt over de toekomst van Jeruzalem is voor de lezers door de loop van de geschiedenis bevestigd.

Een tweede waarneming is dat Lucas een duidelijk onderscheid aanbrengt tussen de verwoesting van Jeruzalem en de komst van de Mensenzoon. We willen dit laten zien aan de hand van het tijdsverloop in Jezus' toespraak over het einde (Lc 21:5-36). In deze toespraak komen beide gebeurtenissen expliciet aan de orde.

$\mathrm{Na}$ de voorspelling van de verwoesting van de tempel in Lucas 21:6 wordt aan Jezus de vraag gesteld wanneer dat alles zal gebeuren en wat het teken daarvan zal zijn

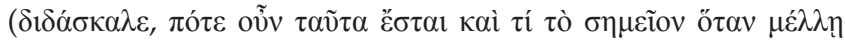

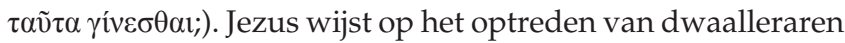
die zeggen dat ze Jezus zijn ( $\dot{\gamma} \gamma \omega \dot{~ \varepsilon i ̉ \mu ı) ~ e n ~ d a t ~ d e ~ v a s t g e s t e l d e ~}$

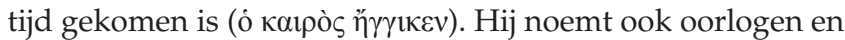
onlusten, maar hij zegt er uitdrukkelijk bij dat dit allemaal eerst moet gebeuren, maar dat dit het einde niet onmiddellijk

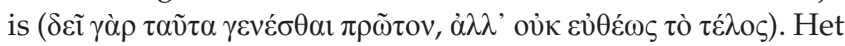
antwoord van Jezus is een ontkenning van de bewering van de dwaalleraren dat de vastgestelde tijd nabijgekomen is.

Na een onderbreking van de directe rede van Jezus door de verteller in vers 10 zegt Jezus dat volkeren en koninkrijken tegen elkaar zullen opstaan, dat er aardbevingen zullen zijn, hongersnood en pest, en dat er zich grote en verschrikkelijke tekenen zullen voordoen aan de hemel. Vooral vanwege het voorkomen van de grote en schrikwekkende tekenen aan de hemel legt Neville de verzen 9 en 10 uit als een samenvatting van alles wat nog volgt in de toespraak van Jezus (Neville 2013:138-139). Hij doet dit vooral omdat hij de tekenen aan de hemel verstaat als de tekenen die vooraf gaan aan de komst van de Mensenzoon. Maar het is goed mogelijk om alles wat genoemd wordt in vers 9 en 10 te verstaan als gebeurtenissen die plaats hebben voorafgaande aan de val van Jeruzalem in 70 na Chr. Voor de oorlogen en onlusten in vers 9 kan men denken aan de joodse opstand, die in 66 na Chr. begon, aan de turbulenties en vele troonswisselingen na de dood van Nero en voor de troonsbestijging van Vespasianus, aan de vele opstanden gedurende het driekeizerjaar, of aan de gebeurtenissen voor de val van Jeruzalem. Vers 10 kan men verstaan als een verbijzondering van vers 9. Voor de natuurrampen van vers 11 kan men verwijzen naar de hongersnood van Handelingen 11:28 en de aardbeving van Handelingen 16:26. De schrikwekkende en grote tekenen aan de hemel hebben bij Flavius Josephus een equivalent in de komeet en in de strijdwagens en soldaten die aan de hemel worden gezien voorafgaande aan de inname van Jeruzalem (Joodse Oorlog 6.288-315). Ook de gebeurtenissen in vers 12

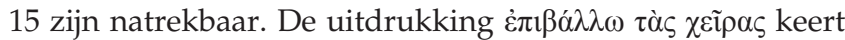
terug in Handelingen $4: 3 ; 5: 18 ; 12: 1 ; 21: 27$. Het gaat daar om de arrestatie van Johannes en Petrus, van de apostelen, van enkele leden van de christelijke gemeenschap en van Paulus. Handelingen vermeldt ook gevangenschappen van volgelingen van Jezus: van de apostelen in Handelingen 5; van Petrus in Handelingen 12; van Paulus en Silas in Handelingen 16 en van Paulus in Handelingen 21:27-28:31. Van de voorleiding voor koningen en gouverneurs is sprake in Handelingen 24 (voorleiding voor Felix), Handelingen 25-26 (voorleiding voor Festus) en Handelingen 25:13-26:32 (voorleiding voor Agrippa).

Vers 12 begint met de vermelding dat voorafgaande aan de gebeurtenissen genoemd in vers 10-11 er vervolging en

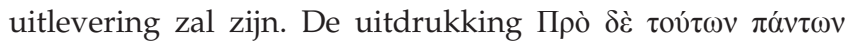
wijst erop dat de gebeurtenissen niet in een chronologische volgorde worden verteld, maar dat de vervolging, de gevangenschap en de vijandschap genoemd in vers 12-19 voorafgaan aan de eerder genoemde gebeurtenissen van vers $10-11$. Wat de leerlingen allemaal te verduren hebben aan arrestaties, gevangenschap en twisten in de eigen familie zal hen gelegenheid geven om te getuigen. Het tekstgedeelte loopt uit op de verzekering dat de leerlingen geen haar op het hoofd zal worden gekrenkt en op de aansporing om te volharden (vers 18-19).

Vanaf vers 20 wordt beschreven hoe Jeruzalem belegerd zal worden en welke gevolgen dat heeft voor de bewoners van Jeruzalem (vers 20-24). Voor de thematiek van dit artikel is het van belang dat de tijd van de belegering en van de val

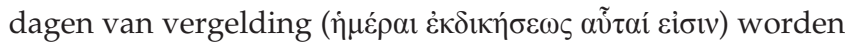
genoemd. Wellicht klinkt hier ook een echo mee van de eschatologische terminologie van Deuteronomium 32:35 LXX (Goldstein 1980), maar de context maakt helder dat de uitdrukking verstaan moet worden als een verwijzing naar de historische gebeurtenissen aan het einde van de joodse oorlog. Vers 24 verwijst naar de tijd van de heidenen, die 
begint met de val van Jeruzalem. De terminologie 'totdat de tijden van de heidenen vervuld zijn' (ő $\chi \rho \imath$ oṽ $\pi \lambda \eta \rho \omega \theta \tilde{\omega} \sigma ı$ каıрoì $\dot{\varepsilon} \theta v \tilde{\omega} v)$ verwijst wellicht eerder naar de tijd van de verkondiging onder de heidenen dan naar een tijd van overheersing door de heidenen.

Neville vindt de cesuur bij vers 25 dat begint met 'Er

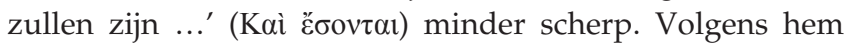
hoeft de cesuur niet scherp te zijn, omdat hij vers 10-11 leest als een samenvatting van de gehele toespraak van Jezus (Neville 2013:140). De verwijzing in vers 11 naar de grote en schrikwekkende tekenen aan de hemel ( $\varphi$ ó $\rceil \tau \rho \alpha ́$

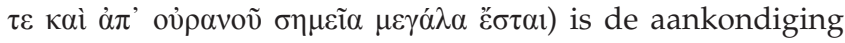
van het deel van de toespraak dat handelt over de komst van de Mensenzoon en de kosmische tekenen die daaraan voorafgaan. Het is inderdaad zo dat de woorden van vers 25 'En er zullen tekenen zijn aan de zon, de maan en de

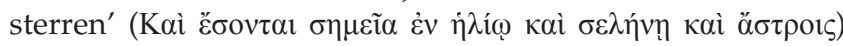
sterk herinneren aan de woorden van vers 11 . Maar als men vers 11 verstaat als verwijzend naar de hemelse tekenen voorafgaand aan de val van Jeruzalem waarover Flavius Josephus verhaalt, vervalt het argument van Neville. Men moet bedenken dat zijn argument ontleend is aan de literaire compositie van de toespraak. Compositie is echter niet geheel hetzelfde als het tijdpad dat in de tekst aanwezig is. Het is vooral het laatste waarin wij op dit moment geïnteresseerd zijn met het oog op de situering van de beoogde lezers. En voor ons is het duidelijk geworden dat de val van Jeruzalem en de tekenen voorafgaande aan de komst van de Mensenzoon uit elkaar liggen en gescheiden worden door de tijd van de heidenen.

Vanaf vers 27 wordt gesproken over de Mensenzoon die komt op een wolk met veel macht en majesteit. In vers 28 wordt deze komst nader gekwalificeerd als de tijd waarin

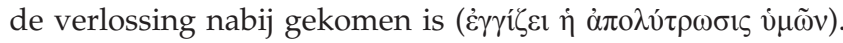
Met deze verwijzing naar het programma van Jezus in het Lucasevangelie wordt helder dat de voltooiing van dit programma gezocht moet worden in de komst van de Mensenzoon. Na de parabel van vers 29-30 wordt bovendien de komst van de Mensenzoon in verband gebracht met de nabijheid van het koninkrijk van God.

Een van de belangrijkste verzen voor de positionering van de beoogde lezers is vers 32: 'Ik verzeker $\mathrm{u}$, dit geslacht gaat niet

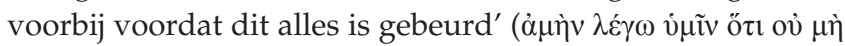

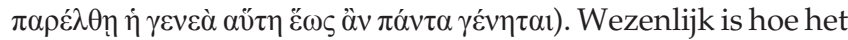
woord $\gamma \varepsilon v \varepsilon \alpha ́$ wordt verstaan. I. Howard Marshall geeft in zijn commentaar de mogelijke betekenissen van dit woord: (1) de afstammelingen van een gemeenschappelijke voorouder; (2) een groep mensen die in dezelfde tijd zijn geboren; (3) de tijd die ingenomen wordt door zo'n groep van mensen of door opeenvolgende groepen (Marshall 1978:780). De meest voor de hand liggende betekenis is dat het in vers 32 gaat om de tijdgenoten van Jezus die zijn toespraak aanhoren. Door de aanhangers van de theorie dat Lucas rekening heeft gehouden met een langdurig uitstel van de parousie, wordt deze interpretatie als een moeilijkheid ervaren. Daarom zijn er alternatieven aangedragen. Robert Maddox somt ze op en bespreekt de validiteit van de argumenten (Maddox 1982:110-115) . De aangedragen alternatieven zijn: (1) het joodse volk; (2) de gehele mensheid (of de niet-christelijke mensheid); (3) Lucas' tijdgenoten; (4) de generatie van Jezus, verstaan als een lang durende generatie vanwege de hoge leeftijd die sommigen van deze generatie hebben bereikt; (5) de laatste fase van de heilsgeschiedenis die meerdere generaties kan omvatten. ${ }^{9} \mathrm{Na}$ bespreking van de argumenten komt Maddox tot de conclusie dat deze alternatieven niet overtuigend zijn. Naar zijn inzicht heeft Lucas de parousie niet naar een verre toekomst verschoven. ${ }^{10} \mathrm{Na}$ zijn onderzoek van de toespraak over het einde concludeert Maddox dat de tekst geen aanleiding geeft tot een theorie over het uitstel van de parousie. Eerder moet men aannemen dat de eschatologische toekomst zeer aanstaande is. Maar tegelijk zijn er ook al elementen vervuld. Ofschoon over de val van Jeruzalem meer in profetische dan in apocalyptische woorden wordt gesproken, geeft de gehele teneur van de toespraak aan dat ook deze gebeurtenis in eschatologische zin moet worden verstaan (Maddox 1982:122-123). Sommige aspecten van de eschatologische toekomst waarover Jezus spreekt, moeten nog gebeuren voor de lezers van het boek van Lucas. Andere daarentegen zijn in hun tijd al gebeurd. Het betekent dat de beoogde lezers deel uitmaken van een eschatologisch gekwalificeerde tijd.

Ons onderzoek van het tijdsverloop in de toespraak van Jezus brengt ons tot de volgende conclusies. Er is een onderscheid tussen de verwoesting van Jeruzalem en de komst van de Mensenzoon. De twee gebeurtenissen komen uit elkaar te liggen doordat de tijd van de heidenen hen scheidt. Voor de toehoorders van Jezus is alles wat Jezus zegt nog toekomst. Dat is het niet voor de beoogde lezers van het Lucasevangelie. Voor hen heeft de val van Jeruzalem en de verwoesting van de tempel in het verleden plaats gevonden. Doordat de woorden van Jezus over deze gebeurtenissen bewaarheid zijn geworden, is het des te waarschijnlijker dat wat Jezus zegt over zaken die voor deze lezers nog toekomst zijn, ook daadwerkelijk zullen gebeuren.

De verwoesting van Jeruzalem en de komst van de Mensenzoon zijn niet alleen onderscheiden van elkaar, ze staan ook met elkaar in verband. Bij beide gebeurtenissen gaat het om de consequenties van aanvaarding of afwijzing van Gods heilsaanbod. Ze staan beide in het kader van Gods bevrijdend initiatief in de geschiedenis, waarover Lucas in zijn boeken verhaalt. Lucas interpreteert de gebeurtenissen van het jaar 70 als een gevolg van de afwijzing van Jezus en diens verkondiging van de vrede door Jeruzalem. Ook

\footnotetext{
9.0ok I. Howard Marshall geeft een opsomming van de interpretaties van dit vers Het kan gaan om: (1) de joodse tijdgenoten van Jezus; (2) het joodse volk; (3) dwaze mensen; (4) de tijdgenoten van de evangelist; (5) de generatie van de eindtijd. Marshall meent dat het vers zo verstaan moet worden dat de huidige generatie er verzekerd van kan zijn dat de gebeurtenissen van de eindtijd zijn begonnen, en dat zij de eindtijd ook zullen meemaken (Marshall 1978:780). Joel B. Green meent dat het vers handelt over mensen die zich verzetten tegen het doel van God (Green 1997.742). Maar men moet er rekening mee houden dat het woord $\gamma \varepsilon v$ ć́ vaak een eschatologische connotatie met zich meedraagt (Hasler 1980).

10.Voor mij is Lucas 18:1-8 steeds een van de overtuigende argumenten geweest dat Lucas de komst van de Mensenzoon spoedig in zijn tijd verwacht. De parabel van de rechter en de weduwe maakt deel uit van een eschatologisch tekstgeheel dat begint in Lucas 17:20. Lucas 18:7-8a verzekert de uitverkorenen die dag en nacht tot God roepen dat Hij spoedig recht zal verschaffen.
} 
in het einde gaat het om aanvaarding of afwijzing van het woord van God. Het lot van Jeruzalem is een afspiegeling van wat mogelijk in het einde kan gebeuren. Maar daarbij geldt wel dat de waarneming van Neville terecht is, dat in de toespraak over het einde de nadruk bij de komst van de Mensenzoon niet ligt op het vergeldingsaspect van het oordeel, maar op de verlossing en de bevrijding van de gelovigen, die Gods bevrijdend handelen in de geschiedenis met volharding hebben aanvaard (Neville 2013:141). Het equivalentie-schema dat we aan het begin van deze sectie hebben gepresenteerd helpt ons om helder te krijgen dat het zowel bij de tijdgenoten van Jezus als bij de beoogde lezers van Lucas gaat om dezelfde transformaties met betrekking tot afwijzing of aanvaarding van de verkondigde vrede en bevrijding.

\section{Het oordeel en het jobeljaar}

De verkondiging van Johannes de Doper in Lucas 3:7-17 is een verkondiging van het oordeel. Dat is zichtbaar te maken aan de terminologie die hij in zijn verkondiging gebruikt.

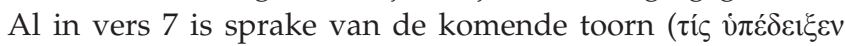

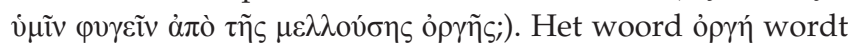
ook gebruikt in Lucas 21:23 in de context van de belegering van Jeruzalem, die een grote nood voor het land wordt

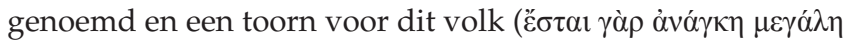

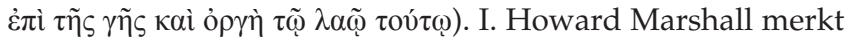
op dat het woord óprí vaak verwijst naar de toekomstige vergelding van God bij het oordeel (Marshall 1978:139). De retorische vraag van Johannes wie gesuggereerd heeft dat het mogelijk is om aan het komende oordeel te ontkomen, impliceert de onmogelijkheid ervan. Het beroep op de afstamming van Abraham in vers 8 wordt door Johannes op tweevoudige wijze ontkracht. Ten eerste is er de

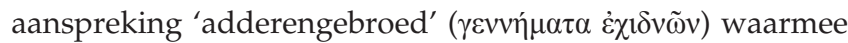
bij voorbaat reeds het vadershap van Abraham is ontkend. ${ }^{11}$ De toehoorders van Johannes stammen niet af van Abraham, maar van slangen. Misschien mag hier meeklinken dat soms de satan als een slang wordt voorgesteld (vgl. Op 12:9). Het tweede punt is dat er bekering nodig is om aan de komende toorn te ontkomen.

In vers 8 wordt bekering verbonden met het voortbrengen

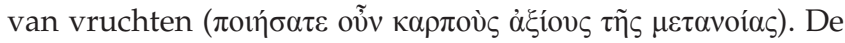
metafoor van het voortbrengen van vruchten loopt vooruit op de opmerking van Johannes in vers 9 dat de bijl al aan de wortel ligt. Met andere woorden, de bomen die geen vruchten voortbrengen, zullen worden omgehakt. Ook in de verkondiging van Jezus worden bekering en vruchten voortbrengen met elkaar in verband gebracht. In Lucas 13:19 spreekt Jezus tegen mensen die hem bericht geven van de moord op de Galileeërs door Pilatus bij hun offer en over de dood van achttien mensen bij het instorten van de toren van Siloam. Hij zegt hen dat ze eenzelfde lot zullen ondergaan

11. Het is opmerkelijk dat Jezus desondanks in het Lucasevangelie tot tweemaal to de afkomst van Abraham gebruikt als een rechtvaardiging van zijn bevrijdend de alkom handelen. In het verhaal van de kromgebogen vrouw rechtvaardigt hij haa genezing op de sabbat met het argument dat zij een dochter van Abraham is (LC 13:16). In Lucas 19:9 rechtvaardigt hij de redding van Zacheüs met het argument dat deze een zoon van Abraham is. tenzij ze zich bekeren. Daarna vertelt hij de parabel van de vijgenboom die geen vrucht voortbrengt. De eigenaar wil de boom laten omhakken, maar de wijngaardenier pleit voor nog een jaar respijt. In deze parabel en in de context waarin deze wordt verteld, treffen we dezelfde gegevens aan als in de prediking van Johannes: de metafoor van het omhakken van de bomen die geen vrucht dragen en de noodzaak van bekering. Een belangrijk verschil is dat in de prediking van Jezus sprake is van uitstel van een jaar, waarin de wijngaardenier zich zal inspannen om het mogelijk te maken dat de vijgenboom wel vruchten draagt.

In verband met de nabijheid van het oordeel en de metafoor van de vruchten willen we ook nog wijzen op de parabel van de wijnbouwers in Lucas 20:9-19. De wijnbouwers mishandelen de drie slaven die achtereenvolgens gestuurd worden om de opbrengst van de wijngaard in ontvangst te nemen. Ze weigeren de vruchten af te dragen. Tenslotte doden ze de zoon van de eigenaar met het oogmerk zich de wijngaard toe te eigenen. De eigenaar zal komen om op zijn beurt de wijnbouwers te doden. In de discussie met zijn toehoorders bekrachtigt Jezus deze afloop met behulp van een citaat uit Psalm 118:22: 'De steen die de bouwlieden hebben verworpen, is de hoeksteen geworden.' Hoe het ook zij, of men nu over deze steen valt of dat deze steen op iemand valt, het heeft de dood tot gevolg. Op twee manieren wordt deze parabel verbonden met de geschiedenis van Jezus. De eerste manier is dat de eigenaar van de wijngaard spreekt over mijn

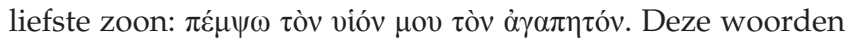
zijn een echo van de stem uit de hemel bij de doop van Jezus: 'Jij bent mijn liefste zoon, in wie ik vreugde vind' (бò عĩ ó vió

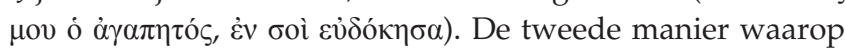
het verband met Jezus wordt gelegd, is de wijze waarop in vers 19 Lucas de reactie van de schriftgeleerden en de hogepriesters beschrijft. Hij verklaart hun voornemen om Jezus te arresteren door te zeggen dat zij wisten dat Jezus op hen doelde. Op metaforische wijze vertelt de parabel over de lotgevallen van Jezus en zijn tegenstanders. De dreiging van het oordeel en de daarbij behorende vergelding blijft aanwezig.

In de zogenoemde Standespredigt ${ }^{12}$ geeft Johannes concrete voorbeelden van bekering voor het volk, voor de tollenaars en voor de soldaten. (Lc 3:10-14). Op de vraag of hij de Messias is, wijst hij op degene die na hem komt en die krachtiger is dan hij. Het verschil tussen hem en degene die na hem komt, legt Johannes uit door te wijzen op het verschil in de wijze van dopen. Johannes doopt met water, maar de Messias doopt met heilige Geest en vuur. Meestal ziet men in de doop met heilige Geest en vuur een verwijzing naar het verhaal over de begiftiging met Geest in Handelingen 2:1-4. De leerlingen raken vol van Geest en vurige tongen zetten zich op ieder van hen neer. Binnen een context van de verkondiging van de komende toorn zijn er echter ook andere verbanden mogelijk. Johannes tekent de sterkere als iemand die oordeel en scheiding komt brengen. De wan heeft

12.H. Schürmann vindt dit een minder gelukkige term, omdat de oproep van Johannes de Doper gericht is tot al zijn toehoorders, onder wie zich ook tollenaars en soldaten bevinden (Schürmann 1969:131). 
hij in de hand. Het graan verzamelt hij in zijn schuur, maar het kaf zal hij verbranden in onblusbaar vuur. Onderdeel van deze metafoor voor het oordeel is dat het kaf wegwaait op de wind of wordt verbrand (zie o.a. Jes 41:15-16; Jer 15:7; Wijsh 5:14; Ps 1:4). In deze context kan dopen met heilige Geest en vuur ook verstaan worden als betrekking hebbend op het oordeel. In dit oordeel bestaat de mogelijkheid gered te worden zoals het koren verzameld wordt in een schuur, of verloren te gaan zoals het kaf verwaait of wordt verbrand.

Uit onze lezing van de verkondiging van Johannes de Doper concluderen we dat deze prediking een aankondiging van het oordeel is. Ze gaat aan de prediking van Jezus vooraf. In diverse teksten blijkt ook dat deze aankondiging van het oordeel blijft meeklinken in de prediking van Jezus. De aankondiging van het oordeel vormt de achtergrond waartegen de prediking van Jezus moet worden verstaan.

Zoals aangegeven keert de metafoor van de vruchten terug in de verkondiging van Jezus. Belangrijk is de parabel van de vijgenboom (Lc 13:1-9). Ook in deze tekst worden de vruchten in verband gebracht met bekering. Aan de toehoorders houdt Jezus voor dat ze hetzelfde lot zullen ondergaan als de vermoorde Galileeërs of als de achttien slachtoffers bij de ramp met de toren van de Siloam, als ze zich niet zullen bekeren. Bekering heeft onder meer als gevolg dat men aan de aangezegde ondergang kan ontsnappen. In dit opzicht is de verkondiging van Jezus congruent met die van Johannes. Belangrijke overkomsten van Lucas 13:1-9 met de prediking van de Doper kan men vinden in de terugkeer van belangrijke

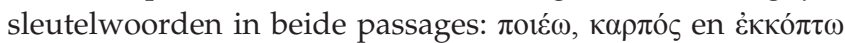
(Green 1997:515). Ook zijn de noodzaak tot bekering en het verwijt aan de toehoorders dat ze denken geen bekering nodig te hebben gemeenschappelijke elementen.

Een belangrijk verschil is echter dat er in de parabel sprake is van een jaar extra voor de vijgenboom. De wijngaardenier houdt bij de eigenaar een pleidooi voor de vijgenboom om hem een jaar extra te gunnen. Hij belooft in dat jaar de omstandigheden voor de vijgenboom te optimaliseren door te spitten en hem te bemesten. Brengt hij dan nog geen vrucht voort, dan kan hij worden omgehakt (Lc 13:8-9).

In mijn ogen is het niet toevallig dat er in de programmatische tekst die Jezus voorleest uit het boek Jesaja bij zijn optreden in de synagoge van Nazaret, eveneens sprake is van een jaar. In Lucas 13:8 is er sprake van ह̌́tos. Dit woord betekent een jaar

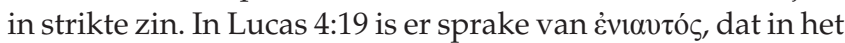
klassieke Grieks een ruimere betekenis heeft: een afgebakende tijdseenheid. Volgens R. Kratz is in het Koine-Grieks van het Nieuwe Testament deze nuancering verloren gegaan (Kratz 1980). Maar wellicht is er toch iets van een verschil tussen de woorden van beide teksten. In het geval van de vijgenboom wordt de tijdsperiode bepaald door de opeenvolging van de seizoenen. ${ }^{13}$ Dat is anders in de programmatische tekst van Lucas 4:18-19. Daar betreft de zinsnede 'een jaar van genade

13.De vijgenboom geeft twee maal per jaar vrucht: in juni de vroege vijg en eind augustus de late vijg. van de Heer' de zending van Jezus. Men kan zich voorstellen dat de periode van de zending van Jezus niet zo door de loop van de seizoenen wordt bepaald als het vrucht dragen van de vijgenboom.

In Lucas 13:8 begint het pleidooi van de wijngaardenier

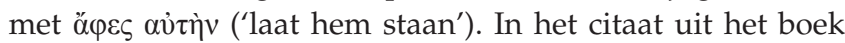
Jesaja, dat Jezus in Lucas 4:18-19 voorleest, speelt het woord

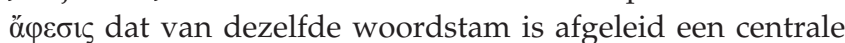
rol. De tekst die Jezus voorleest is geen rechtstreeks citaat, maar een vermenging van Jesaja 61:1-2 en Jesaja 58:6. Jesaja 61:1-2 speelt een belangrijke rol in het evangelie van Lucas. Men kan echo's van de tekst horen in de zaligsprekingen en weeroepen (Lc 6:20-26). Ook in Lucas 7:22 kan men Jesaja 61:1-2 mee horen klinken, wanneer Jezus aan de leerlingen van Johannes antwoordt: 'Ga aan Johannes vertellen, wat $\mathrm{u}$ hebt gezien en gehoord, blinden zien weer, kreupelen horen, melaatsen worden rein, doven horen, doden staan op, en aan armen wordt de goede boodschap verkondigd.' Door de samenvoeging met Jesaja 58:6 komt in Lucas 4:18-19 de nadruk op het woord ö $\varphi \varepsilon \sigma ı \varsigma$ te liggen, ${ }^{14}$ dat in deze context vrijheid en vrijlating betekent, maar dat ook kwijtschelding, verzoening en vergeving kan betekenen, vooral in de woord combinatie $\alpha \varphi^{\prime} \varepsilon \sigma \iota \varsigma \dot{\alpha} \mu \alpha \rho \tau \imath \tilde{\omega} v$ (vergeving van de zonden). De terminologie, in het bijzonder in de combinatie 'de gevangene vrijlaten', roept de gedachten op aan het jobeljaar dat in Leviticus 25:10 (LXX) 'een jaar van

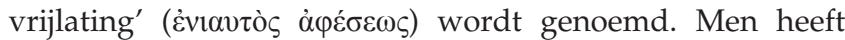
verondersteld dat in de eredienst van de synagoge reeds in het begin van de eerste eeuw Leviticus 25 en Jesaja 61 een vaste combinatie van lezingen is. Aangetoond is dat in Qumran de combinatie aanwezig is (zie de Jonge \& van der Woude [1965] 1966). Het optreden van Jezus, zoals Lucas dat schildert, is een actualisering van het jobeljaar. Meerdere auteurs spreken daarom ook van een lucaanse theologie van het jobeljaar (Swartley 2006:137-138). Voor onze studie naar de verhouding van Jezus' verkondiging van vrede, geweldloosheid en vijandsliefde aan de ene kant en het geweld van het oordeel aan de andere kant is het bijzonder zinvol dat het citaat afbreekt voor 'een dag van vergelding voor onze God'. Vergelding maakt geen deel uit van de verkondiging van Jezus.

Men kan dus het optreden en de verkondiging van Jezus opvatten als het jaar respijt dat de vijgenboom krijgt om alsnog vruchten te dragen. De tekst van Lucas 4:18-19 beschrijft dit optreden als de aankondiging van een genadejaar van de Heer. Bart Koet heeft in zijn studie naar de verkondiging van Jezus in de synagoge van Nazaret laten zien dat de programmatische tekst die Jezus voorleest tevens een oproep tot bekering impliceert (Koet 1989:24-55). ${ }^{15}$ Koet noemt meerdere elementen die hierop wijzen. In Lucas is de aankondiging van het goede nieuws voor de armen meestal gekoppeld aan een oproep voor de rijken om zich te bekeren en van hun rijkdom te delen. De afkondiging van het jobeljaar impliceert een oproep tot bekering voor hen die het aangaat:

14.Verhelderend is nog steeds de analyse van J. Kahmann (Kahmann 1975).

15.Dit hoofdstuk uit het proefschrift van B. Koet is eerder gepubliceerd als Koet (1986). 
vooral voor de welgestelden die leven ten koste van anderen.

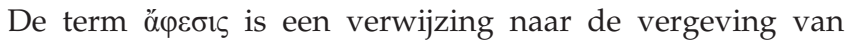
de zonden. Behalve in Lucas 4:18-19 verschijnt het woord steeds in de woordcombinatie ö $\varphi \varepsilon \sigma 1 \varsigma \dot{\alpha} \mu \alpha \rho \tau \imath \tilde{\omega} v$ (vergeving van de zonden). Op vele plaatsen in het Lucasevangelie is bekering een voorwaarde voor de vergeving van zonden. Koet concludeert dat de profetische boodschap van Jezus de toehoorders de mogelijkheid biedt om te kiezen tussen aanname of afwijzing van de verkondiging van bekering en vergeving van zonden (Koet 1989:34-35). In het vervolg van zijn studie laat hij zien dat de oproep tot bekering ook in de volgende fasen van de interactie tussen Jezus en zijn toehoorders in de synagoge aanwezig is. De toehoorders staan voor de keuze om het aanbod van de goede boodschap en de daarbij behorende oproep tot bekering aan te nemen of af te wijzen.

Omdat Lucas 4:18-19 een programmatische functie heeft voor het hele optreden van Jezus is de aankondiging van het genadejaar van de Heer niet alleen gericht tot de aanwezigen in de synagoge, maar ook bedoeld voor alle personages in het boek. De aankondiging van het oordeel door Johannes de Doper is gericht tot alle personages, maar het optreden van Jezus dat als een jaar respijt kan worden beschouwd, is ook ten behoeve van allen.

In de afwijzing van de boodschap van Jezus door Jeruzalem is enige dramatiek besloten. Die wordt zichtbaar onder meer in de klacht van Jezus over Jeruzalem (Lc 19:41-44). Allereerst is het belangrijk de emoties van Jezus te onderkennen die

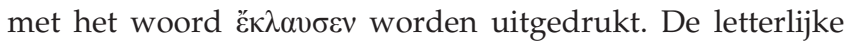
betekenis van het werkwoord $\kappa \lambda \alpha i \omega$ duidt op het verdriet en de klacht over een dode of over wat verloren is, op het verdriet bij een afscheid of op de schok bij het zien dat men zelf verloren gaat of bij de ontoereikendheid van anderen (Balz 1981). Het gaat om een intense emotie. Dezelfde betekenis is aanwezig bij de ontmoeting van Jezus met de vrouwen uit Jeruzalem in Lucas 23:27-31. Jezus spreekt de vrouwen aan en zegt dat ze niet om hem en zijn aanstaande dood moeten rouwen en treuren, maar om haarzelf en haar kinderen en om het lot dat Jeruzalem wacht. Al eerder heeft Jezus zijn verdriet over het lot van Jeruzalem getoond. In Lucas 13:34-35 beschrijft Jezus hoe Jeruzalem de profeten doodt en de mensen die naar de stad toegezonden zijn stenigt. Hij heeft de kinderen van Jeruzalem onder zijn hoede willen nemen, zoals een kip haar kuikens. Maar ze hebben het niet gewild. Daarom zal hun huis onbewoond worden achtergelaten. Belangrijk is het steeds de tonen van verdriet en rouw te horen in de woorden die Jezus over Jeruzalem spreekt. Het maakt duidelijk dat Jezus niet uit is op vergelding, maar er om rouwt.

De klacht van Jezus over Jeruzalem in Lucas 19:42-44 bevat enkele duidelijke verwijzingen naar het optreden van Jezus. Zo is de zinsnede 'de weg van de vrede' ( $\tau$ ò $\pi \rho$ ò een verwijzing naar de vredesverkondiging van Jezus. Ook in vers 44 is er een dergelijke verwijzing, waar het gaat over

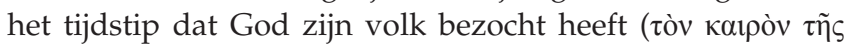
$\dot{\varepsilon} \pi \imath \kappa \kappa \pi \tilde{\Upsilon} \varsigma$ боv). In deze woorden herkennen we de manier waarop Lucas het optreden van Jezus associeert met het verhaal van de bevrijding uit Egypte, en daarmee ook het exodusmotief dat genoemd wordt in het verhaal van de verheerlijking op de berg. Maar tegelijk is ook hoorbaar in de tekst dat Jeruzalem de tijd voorbij heeft laten gaan. De weg naar de vrede bleef voor haar ogen verborgen (vṽv $\delta \dot{\varepsilon} \varepsilon \dot{\varepsilon} \kappa \rho v ́ \beta \eta$

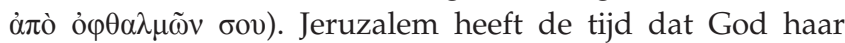

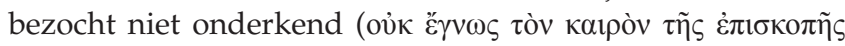
бov). Dat Jeruzalem, de stad wier naam met vrede wordt geassocieerd, ${ }^{16}$ de weg van de vrede niet heeft onderkend, is bijzonder navrant.

Tenslotte merken we nog op dat de woorden van Jezus in Lucas 19:42-44 gekenmerkt worden door een eschatologischapocalyptisch taalspel. Formuleringen als 'op die dag' en het noemen dat geen steen op de andere zal blijven, maken ook in andere teksten deel uit van dit taalspel. Het wijst erop dat in de lucaanse visie de val van Jeruzalem, hoewel die duidelijk onderscheiden is van de komst van de Mensenzoon in het einde, wel degelijk deel uitmaakt van de eschatologische tijdsordening van dit evangelie.

\section{Het uitstel van de parousie als een genadejaar}

Het geheel overziende mogen we concluderen dat Lucas' visie op het definitieve ingrijpen van God in de geschiedenis niet beperkt is tot de gebeurtenissen aan het einde bij de komst van de Mensenzoon en de definitieve vestiging van het koninkrijk van God. De eschatologie van Lucas begint met de aankondiging van het oordeel door Johannes de Doper. Maar de eschatologische tijd moet men niet opvatten als een massief geheel. Deze tijd is zelf weer geleed. Er is een periode tot aan de val van Jeruzalem en er is een periode voorafgaande aan de komst van de Mensenzoon. De tijd van het optreden van Jezus is een tijd van uitstel, van het genadejaar van de Heer, waarin de boodschap van vrede en bevrijding wordt gerealiseerd. In deze tijd is er ook de ruimte om zich te bekeren. Wanneer men echter de weg van de vrede en de tijd dat God zijn volk heeft bezocht niet heeft onderkend volgt het oordeel. In het evangelie is Jeruzalem daar een specifiek voorbeeld van. Degenen die deze weg en deze tijd wel hebben onderkend, worden de vrede en de bevrijding deelachtig.

Voor de beoogde lezers van het evangelie van Lucas zijn de gebeurtenissen rond de val van Jeruzalem verleden tijd. Maar deze gebeurtenissen zijn wel equivalent en congruent met de tijd van de beoogde lezers. Ze leven in de tijd voorafgaande aan het einde. Ook hun tijd kan beschouwd worden als een genadejaar van de Heer. Ook zij hebben de mogelijkheid de weg van de vrede te onderkennen en de tijd dat God zijn volk heeft bezocht. Ook voor hen is er de mogelijkheid van bekering. Wordt deze niet onderkend dan volgt voor hen, net zoals voor Jeruzalem, de vernietiging. Maar wordt deze tijd wel onderkend, dan is voor hen met de komst van de Menszoon de verlossing nabij.

16.J. Fitzmyer noemt de relevante plaatsen (Fitzmyer 1985:1256-1257) 
We beseffen dat we met onze lezing van het Lucasevangelie de frictie tussen vrede en geweld in dit evangelie niet helemaal hebben opgelost. Vooral de parabel van de edelman die het koningschap verwerft, blijft een dwarse tekst. Maar wel hebben we met onze lezing het perspectief van de problematiek veranderd. Het is niet meer zo dat we moeten verklaren dat er na een verkondiging en een praktijk van vrede en bevrijding, een oordeel en vergelding komt. Nee, het eerst is er de aankondiging van oordeel en vergelding. Daarbij wordt er een uitstel gerealiseerd dat bekering mogelijk maakt. Dat uitstel maakt vrede en bevrijding mogelijk.

\section{Tegenstrijdige belangen}

De auteur verklaart geen financiële of persoonlijke belangen te hebben die hem ongepast kunnen hebben beïnvloed bij het schrijven van dit artikel.

\section{Literatuurverwijzingen}

Balz, H., 1981, s.v. ' $\kappa \lambda \alpha{ }^{\prime} \omega$ ', in Exegetisches Wörterbuch zum Neuen Testament, W. Kohlhammer, Stuttgart, Berlin, Köln and Mainz, Band II, pp. 725-727.

Cassidy, R.J., 1978, Jesus, politics and society: A study of Luke's gospel, Orbis, Maryknoll, NY.

Fitzmyer, J.A., 1985, The Gospel according to Luke (X-XXIV): Introduction, translation and notes, Doubleday, Garden City, NY.

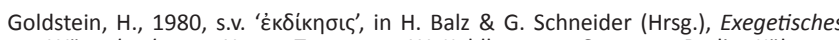
Wörterbuch zum Neuen Testament, W. Kohlhammer, Stuttgart, Berlin, Köln and Mainz, Band I, pp. 991-993.

Green, J.B., 1997, The Gospel of Luke, Eerdmans, Grand Rapids, MI/Cambridge.

Hasler, V., 1980, s.v. ' $\gamma \varepsilon v \varepsilon \alpha$ ', in Exegetisches Wörterbuch zum Neuen Testament, W. Kohlhammer, Stuttgart, Berlin, Köln and Mainz, Band I, pp. 579-581.

lersel, B. van, Schaik, T. van, Tilborg, S. van, Welzen, H. \& Weren, W., 1987 Parabelverhalen in Lucas, van semiotiek naar pragmatiek, Tilburg University Press, Tilburg.
Jonge, M. de \& Woude, A.S. van der, [1965] 1966, '11 Q Melchisedek and the New Testament', New Testament Studies 12, 301-326. http://dx.doi.org/10.1017/ S0028688500018117

Kahmann, J., 1975, 'Hetwoord van bevrijding: Redactieen interpretatie in Lucas 4,16-30', in A. Blijlevens e.a. (reds.), De weg van het woord: Een bundel opstellen over Gods woord in mensenwoorden, opgedragen aan F. van Trigt, pp. 44-63, Gooi en Sticht, Hilversum.

Koet, B.J., 1986, "'Today this scripture has been fullfilled in your ears": Jesus' explanation of scripture in Lukas 4,16-30', Bijdragen 47, 368-394.

Koet, B.J., 1989, Five studies on interpretation of scripture in Luke-Acts, pp. 24-55, University Press, Peeters, Leuven.

Kratz, R., 1980, s.v. 'Ėvıviós', in Exegetisches Wörterbuch zum Neuen Testament, W. Kohlhammer, Stuttgart, Berlin, Köln and Mainz, Band I, pp. 1110-1111.

Maddox, R., 1982, The purpose of Luke-Acts. Vandenhoeck \& Ruprecht, Göttingen.

Marshall, I.H., 1978, The Gospel of Luke: A commentary of the Greek text, Pater Noster Press, Exeter.

Massyngbaerde Ford, J., 1984, My enemy is my guest: Jesus and violence in Luke, Orbis Books, Maryknoll, NY.

Neville, D.J., 2013, A peacable hope: Contesting violent eschatology in New Testament narration, Baker Academic, Grand Rapids, MI.

Schürmann, H., 1969, Das Lukasevangelium, Erster Teil, Herder, Freiburg, Basel and Wien.

Swartley, W.M., 2006, Covenant of peace: The missing peace in New Testament theology and ethics, Eerdmans, Grand Rapids, MI/Cambridge.

Tilborg, S. van, 1987, 'De koning en de tien slaven (Lc 19,1-27)', in B. van lersel, T. van Schaik, S. van Tilborg, H. Welzen \& W. Weren (reds.), Parabelverhalen in Lucas, van semiotiek naar pragmatiek, pp. 217-250, Tilburg University Press, Tilburg.

Welzen, H., 1986, 'Lucas, evangelist van gemeenschap: Een onderzoek naar de effecten in Lc 15,1-17,10', Proefschrift, Universiteit te Nijmegen.

Welzen, H., 1987, 'Naar een pragmatiek van het Lucasevangelie', in B. van lersel, T. van Schaik, S. van Tilborg, H. Welzen \& W. Weren (reds.), Parabelverhalen in Lucas, van semiotiek naar pragmatiek, pp. 281-321, Tilburg University Press, Tilburg.

Welzen, H., 2008, "'Were not our hearts burning within us while he was talking to us on the road, while he was opening the Scriptures for us?" (Luke 24:32): Spiritual
hermeneutics as a heuristic model for the spiritual aspects of intertextuality within the Lucan Corpus', in H. Blommestijn, C. Caspers, R. Hofman, F. Mertens, within the Lucan Corpus', in H. Blommestijn, C. Caspers, R. Hofman, F. Mertens, P. Nissen \& H. Welzen (eds.), Seeing the seeker: Explorations in the discipline of
spirituality - A festschrift for kees waaijman on the occasion of his 65th birthday, spirituality - A festschrift for kees waaijman on the
pp. 169-197, Peeters, Leuven, Paris and Dudley.

Welzen, H., 2013, 'Spiritualiteit van het Lucasevangelie: Verwachting en volharding', Acta Theologica 33(1), 292-314.

Yoder, J.H., [1972] 1994, The politics of Jesus: Vicit agnus noster, rev. edn., Eerdmans, Grand Rapids, MI. 